\title{
Article \\ Digital and Media Literacies in the Polish Education System-Pre- and Post-COVID-19 Perspective
}

\author{
Karina Cicha ${ }^{1}$, Paulina Rutecka ${ }^{2}$, Mariia Rizun ${ }^{2}$ (D) and Artur Strzelecki ${ }^{2, *(\mathbb{D})}$ \\ 1 Department of Communication Design and Analysis, University of Economics in Katowice, \\ 40-287 Katowice, Poland; karina.cicha@ue.katowice.pl \\ 2 Department of Informatics, University of Economics in Katowice, 40-287 Katowice, Poland; \\ paulina.rutecka@ue.katowice.pl (P.R.); mariia.rizun@ue.katowice.pl (M.R.) \\ * Correspondence: artur.strzelecki@ue.katowice.pl
}

check for

updates

Citation: Cicha, K.; Rutecka, P.;

Rizun, M.; Strzelecki, A. Digital and

Media Literacies in the Polish

Education System-Pre- and

Post-COVID-19 Perspective. Educ. Sci. 2021, 11, 532. https://doi.org/

10.3390/educsci11090532

Academic Editors: Christian

M. Stracke, Daniel Burgos, Jon Mason, Cleo Sgouropoulou and Jin Gon Shon

Received: 13 July 2021

Accepted: 6 September 2021

Published: 10 September 2021

Publisher's Note: MDPI stays neutral with regard to jurisdictional claims in published maps and institutional affiliations.

\begin{abstract}
Digital and media literacies refer to a specific set of skills and abilities. The range of these skills as they concern the educational process has been broadly discussed. In this paper, we analyzed the Polish educational system to determine the scope of the sorts of digital skills young people and students should achieve in order to be considered digitally and media literate. We compared sets of recommendations from the last ten years issued by different national governmental and nonprofit organizations for the Polish education system. We identified a set of skills that should be expected to be possessed by young people and students during their education. Additionally, we discussed results regarding the situation caused by the COVID-19 pandemic and the shift from regular education to distance learning.
\end{abstract}

Keywords: digital literacy; media literacy; education system; COVID-19

\section{Introduction}

Communication competence [1] is the basic term for journalism students and those involved in the field of communication sciences. Based on the model of communication by Roman Jakobson [2], the phenomenon of transmitting and receiving messages by participants of the communication process was analyzed, most often by asking two questions. The first concerned the conditions in which communication is effective, and the second focused on the communication competence of participants of this process. It has been emphasized in the works of Noam Chomsky and Dell Hymes [3] that communicative competence is a concept broader than linguistic competence. If we assume, following Chomsky, that we are linguistically competent when we can generate an infinite number of sentences from a finite set of elements, then we are communicatively competent when we extend our arsenal to every possible method of communicating, i.e., when we go beyond the language. Therefore, the range of measures used must include both nonverbal communication (in all of its forms) and the ability to create and read visual messages (media and artistic) or knowledge of cultural scripts.

Nowadays, in the age of communication, transmitting messages that reach the recipient via their sense of sight seems to have become extremely important. These communication methods are mediated more and more often through media, often through computer-mediated communication. While the literacy process assumes that students are learning to read and write-and thus acquiring the skills of verbal communication in its written form during school education-visual communication, or conveying content through a visible medium, such as text or images [4], is rarely mentioned. This is because we believe that we can understand images to the same extent as words and that we acquire this skill not through the teaching process but through contact with visual culture and its products. 
Meanwhile, as noted by Nicholas Mirzoeff, the gap between the level of visual experience and the ability to analyze these findings determines the possibilities of emerging visual culture, as well as the need for it to emerge as a subject of research [5]. His remarks provoked questions about the elements and competencies of visual culture (e.g., photo, graphics, infographics, diagrams, visualizations) that have been subjected to scientific analysis. It is thanks to this that the presented analysis was possible to conduct.

The term visual literacy, understood as the necessary ability of a contemporary person to absorb content received through various media, was coined in 1969 by John Debes. Debes defined it as a group of visual competencies. As of the present day, numerous other definitions of the term have arisen.

The problematic nature of defining visual literacy stems in part from an interdisciplinary perspective [6]. However, most researchers have defined visual literacy as the ability to create and understand meaning communicated through images [7]. Some researchers, such as Peter Felten or Paul Martin Lester, added cultural aspects of the process to the definition $[8,9]$.

According to Lester, cultural differences are related to growing up in a specific environment and assimilating the cultural patterns (scripts) offered by it, and also to the process of education, i.e., acquiring knowledge and skills as a result of an institutionalized process. In Lester's view, the school is crucial because the competencies required of students are typically written into the teaching process. Visual literacy is a communicative competence because, while communicating, we also focus on the effectiveness of the whole process. By learning to read and write (during the teaching process), we become communicatively competent, referring to the linguistic aspect of communicative competence.

However, there are terms in the literature, such as media competencies, media literacy, and digital competencies, which refer to a particular set of skills and abilities that expand the definition of visual literacy. What is more, the range of those competencies has been broadly discussed as it concerns the educational process. Analyzing the Polish educational system, questions arise concerning the sorts of digital skills students must achieve to be considered digitally and media literate. Are those competencies developed through the educational process? Are the digital skills developed through the teaching process sufficient in times of remote learning?

Therefore, the authors formed the following research questions:

RQ1: What sorts of skills are included in the phrase "digital and media competencies" for Polish pupils and students?

RQ2: Is the set of digital and media competencies defined in Polish catalogs adequate with respect to documents prepared in other EU countries?

RQ3: How did the digital literacy level of pupils, students, and teachers affect the impact of the COVID-19 pandemic on education?

Answers to these three research questions form the content of the following sections of this paper.

\section{Literature Review}

\subsection{Digital Literacy—Ordering the Definitions}

The dynamic development of technologies and their increasing importance in everyday life have been observed for years. Although the Internet was initially used only by researchers and a small group of people with the specific skills required to utilize the technology [10], it quickly entered into widespread use [11]. The widespread use of the Internet and the implementation of ubiquitous technological solutions for businesses [11] meant that the world increasingly needed a new generation. This new generation needs the skills to use computer technologies [12], to understand and manage resources in digital formats [13], and, at the same time, to be aware of the dangers that result from using them. Research conducted between 2002 and 2012 showed that over $90 \%$ of teenagers regularly use the Internet [11], mainly for communication. Children already use computers, smartphones, and tablets at the age of 2 [14]. By using these devices, they are forced to 
interact with emerging messages and, at the same time, are exposed to digital dangers. Moreover, research indicates that children do not have adequate knowledge about the risks associated with inappropriate use of the Internet and are prone to cyberbullying [11]. Realizing that younger and younger people have contact with digital messages means that nowadays, reading and writing are already taught in kindergarten [15], and digital skills are developed from the early years of schooling [16]. Young people, including students, also understand the need for digital competencies that will allow them to better engage in learning, find a job in a dynamically changing work environment after graduation [17], and further develop professionally and personally [14].

Originally, the term "digital skill" was used to describe the minimum set of technical skills that allowed the performance of tasks and operation of new technology devices efficiently [18]. Over time, the number of definitions grew, and the definitions themselves went through a natural evolutionary process. Lankshear and Knobel point out that the concept of digital literacy is defined in a variety of ways. On the one hand, it is the definition of digital literacy itself [19]; on the other, it is a set of national or international rules that standardizes digital literacy. There are now over 100 models and frameworks that try to capture different dimensions of digital skills [14]. However, even though various certificates such as ECDL are created, their possession is not synonymous with being digitally literate. Those certificates do not declare specific competencies [13]. They most often refer to computer skills [20] and do not take into account social aspects [19]. Alternatively, the term "digital literacy" is also used as digital competence, media literacy, multiculturalism, and new literacy [21].

Later success in school depends on literacy development in the early years [15], but with the development of technology, the nature of information has changed. Digital information is more multimedia, and its understanding requires not only "literacy" but also the ability to read the information presented in any way, consisting of images and sounds [22]. Similar conclusions were presented by O. Erstad, who, apart from the necessity to redefine literacy skills, noted that the development of digital technologies "changes our concepts of text, readers, and writers" [16,23]. The very concept of digital literacy was introduced by Gilster in 1997, and was defined as the ability to understand and use information in many formats from many different sources when presented through computers [19,24]. Shortly after, Pool described digital skills as the ability to adapt to new media [25]. He pointed out that media users' experiences will depend on their competencies in using it [24]. Both early definitions indicate technical skills in the use of tools. In 2005, Martin redefined digital literacy as the awareness, attitude, and ability of people for appropriate usage of digital tools and facilities to build effective and adequate communication in a social context and manage it [26]. Thus, he referred to Bawden's approach, who pointed out that apart from the mere ability to use tools and read multimedia messages, it is also necessary to develop the ability to extract meaning from what is read [27]. With this in mind, in 2017, Chan proposed another definition of digital literacy that addressed the issue of understanding and using the information in multiple formats, emphasizing critical thinking rather than ICT skills [24,28]. The importance of the term digital literacy is reflected in the standardized definition of this term adopted by the European Parliament and the European Council as one of the eight key competencies for lifelong learning $[29,30]$.

\subsection{Media Literacy-Ordering the Definitions}

In digital reality, the media also lose their original character, and the classical division into mass media and technologies (ICT) is becoming increasingly obsolete [12]. Clearly defined frames that characterized a given medium (e.g., text and photos as forms reserved for the newspapers) blur, and new technologies allow the forms to interweave, requiring a change in journalists' approach [31] and the teaching of journalism students.

In 2004, Potter developed a cognitive information processing framework that assumes that media literacy is facilitated by increasing media literacy (about media content, effects, 
industries, etc.). Individual media competencies, including critical media analysis, are improved by the effort put into information processing [32].

The freedom in creating and accessing the media meant that the level of media consumption increased. Due to this fact, the media recipients must be able to perform a critical analysis of the audiovisual products they consume [33]. However, it is not synonymous with the ability to fully understand them [34]. It is necessary to critically analyze the audiovisual products [33] in order not to lose distance from them and not to allow fiction and reality to blur [34], and not to perceive facts as someone's opinion [21]. For this purpose, the critical role of school in the teaching process is emphasized. When working with media texts, the school can engage students in critical analysis by persuading them to deconstruct and reconstruct them to understand them more deeply [35].

The media, which has also been pointed out by the researchers, have a high potential for disseminating stereotypes [32], which, combined with the lack of criticism towards the received message, may hurt both the unskillful recipients of audiovisual messages and the social groups affected by these stereotypes. Reproducing these stereotypes, as well as engaging in the life of online communities that bring together people who are negative about race, ethnicity, gender, and sexual identity, may lead to cyberbullying [32,36]. Therefore, media education is aimed at, among others, protecting young people from the harmful effects of media messages [37], and might be an essential counter-measure [38]. The teachers should engage in critical conversations about media and technology, including social media and desired behaviors [36]. Today, young people are not only consumers of media but also take an active part in creating it [39]. They create blogs or social media content and audiovisual content used on YouTube or TikTok. To consider a person competent in audiovisual communication, the person creating messages must make them understandable and effective in communication [33].

The issues mentioned above indicate the critical necessity of media education combined with digital education, concerning security and threats on the Internet and threats resulting in misunderstood media messages. Media literacy is a broad term, extending much further than just the skill of using the media. In the United States, it encompasses a range of communication competencies, such as the ability to access, analyze, evaluate, and communicate information in various forms [40]. On the more detailed level, media literacy is defined as fluency in fields such as:

- Critical awareness of the impact of the media on individuals and society;

- Understanding the nature and functioning of the media industry and the characteristics of the media;

- Ability to analyze the media;

- Critical media evaluation;

- Learning through media;

- Creative expression;

- Ability to monitor and criticize the media;

- Practicing media ethics;

- Constructive application in everyday life of what the media has taught [39].

The term media literacy, regarding a digital media environment, is considered a set of skills required to produce effective digital media content [41] and refers to:

- Technical skills related to the use of computers, software, and applications to create digital content [42];

- Audiovisual skills related to understanding and applying the principles of digital media to media artifacts $[43,44]$;

- Behavioral skills related to knowing what is acceptable in internet communication [45,46];

- Critical skills related to the ability to search, identify, analyze, and evaluate online content for its credibility [47];

- Social skills related to effective interactions with other Internet users [48]. 
Finally, all of the components of the media literacy definition can be divided into general fields in which a competent media user or literate media user, to be more precise, should present fluency. Those fields stand as follows:

- Language: the knowledge of codes, the ability to use them, and to analyze written and audiovisual messages from the perspective of meaning, narrative structures, categories, and genres.

- Technology: the knowledge and the ability to use tools enabling written and audiovisual communication.

- Interaction processes: the ability to critically evaluate cognitive, rational, emotional, and contextual elements that interfere with perception.

- Production and diffusion processes: the ability to develop, select, share, and disseminate media messages.

- Ideology and values: the ability to comprehensively and critically read, analyze, and select media messages to represent reality.

- Aesthetics: the ability to analyze and evaluate audiovisual messages from the aesthetic point of view [33].

The selected and gathered definitions of both digital literacy and media literacy show a certain overlap between them. However, the constant broadening of the definitions related to the media changes observed globally indicates that while discussing obtaining skills through an educational process, one should consider using the term digital and media literacy to emphasize their complex structure and multi-dimensional nature.

\subsection{Digital and Media Literacy in Education}

Due to the conscious need to shape digital and media competencies, it was necessary to systematize them and include them in the education system. Over the past decade, the United Nations for Education and Culture (UNESCO) has promoted the new concept of media and information education (MIL), arguing that in the digital age, media literacy should integrate with information skills and ICT skills so that people can learn how to deal with media messages and information from all sources and platforms [39].

According to estimates, a student of a Polish public school participates in 14,700 teaching hours during education from the first grade of primary school to the fourth grade of high school. At school, the development of digital and media skills (called "computer science" in Polish curricula), defined as a critical condition for the success of students [13] in the process of online education [49] and lifelong learning [50], is planned for one hour a week, which amounts to about $30 \mathrm{~h}$ a year. What is more, media use in classes other than computer science is rare and not a common practice. In primary school (for eight years) and high school (for four years), approximately $360 \mathrm{~h}$ is allocated to learning computer science, accounting for approximately $2.5 \%$ of all teaching hours in the entire education process. During this time, the student should learn to use technology, including software operation and safety rules. However, this use cannot be limited to the ability just to press keys [19], because the ability to use a computer has become an insufficient criterion for defining digital skills [13] and is insufficient for learning in the digital world [18,51]. Above the skills already mentioned, researchers also point out as important the skills of effective problem solving, critical thinking and communication, creativity, and self-regulation, along with an understanding of culture-based and context-based practice in using digital technologies [18,19,27,51].

A revolution in the approach to education was introduced by Prensky's concept of digital natives while facing increased criticism. On the one hand, it is difficult to disagree with the statement that today's students are no longer the people our educational system was designed to teach [52], and to question that today's students are completely different from students of all previous generations. Prensky persuades teachers to change their approach to education by adapting the way of presenting the material to the different functioning of the brain [20] of Generation Z students, whom he calls the native speakers of the digital language of computers, video games, and the Internet [52], and whom he 
considers technology experts. On the other hand, some studies show that older students (born before 1984) show more traits attributed to digital natives than Gen Z students [53], and that the fact that they use technology every day for communication and entertainment purposes is not equal to the ability to use technology for learning [54]. The second argument is supported by the fact that they cannot criticize the truthfulness of the information and are likely to be frustrated if the answers are not immediately clear [20]. It is necessary to teach students how to assimilate information, evaluate it, and then reintegrate it [55]; otherwise, they will download information from the web. Without reading it and analyzing critically, they will paste this information into their collection of quotations [19].

It cannot be assumed that the mere fact of being born at a specific time and having access to technology is tantamount to the ability to operate it [13], nor can it be assumed that everyday media consumption guarantees the acquisition of the ability to use it [34]. It is necessary to build the ability to use digital technologies and media to serve the interests of their users [21] consciously. It is also necessary to introduce innovation, teaching how students are best able to learn [56,57], and taking into account new technologies that are ubiquitous in their lives. It is important to rebuild the way classes are conducted to allow students to use technology they feel natural with, rather than trying to catch up with technology [58]. However, these changes are complicated to implement in bureaucratic education systems.

Experts from various countries pointed to the resistance of administrative bodies as one of the most significant challenges in the design and implementation of digital and media literacy into curricula [59], although some schools, e.g., in Hong Kong, include information technology (IT) in media education [39], and students use laptops in the classroom to explore and discuss media issues. The aim is to equip students with IT skills for effective information processing in the digital age [39]. However, this requires not only equipping schools with technology but also emphasizing the professional development of the teachers [60] so that they can teach people from the digitized generation [52] and use technology in classes [39] to teach other subjects. It is also important to teach by problem solving and include in the education process projects assuming interdisciplinarity and practical experience [61] to strive for education that meets sustainable development goals [61-63].

At present, the researchers indicate that teachers understand the concept of digital and media literacy rather intuitively and have to develop their digital skills on their own, while teaching and assessing their students' digital skills [14]. Students, at the same time, notice and live with the belief that they are more digitally skilled than their professors [58]. Teachers must learn who the students of the new generation are [18,39] to implement digital education and media-assisted education properly. The use of computer systems also allows collecting data on students, their problems, and successes. These are vast collections of educational data, the analysis of which can contribute to the identification and understanding of problems in the education system [64]. Although in Poland, several media literacy diagnoses have already been conducted, either by the appointment of the Polish Ministry of Education and Science or non-governmental organizations, for students and adults, there has still been a lack of consistent and comprehensive study on this matter [65].

\section{Materials and Methods}

Pupils in the Polish educational system learn in two types of school: from age 7 to 15 they attend primary school, and from age 15 to 19 they attend secondary school (high school). After finishing high school and passing the high school exam, they may apply for college admission. Schools are mostly public, governed by the state. For every level of education, the Polish Ministry of Education and Science defines sets of competencies required for students to obtain during the educational process. Digital and media competencies are one of those sets. 
The research approach for this paper focused on comparing and analyzing the reports available for Polish teachers, prepared by non-governmental organizations between 2010 and 2020. The search for reports included two basic features: presence in Google Scholar base and keywords such as "media competencies", "digital competencies", and "digital competencies in education". The search took place in Polish. Those reports which clearly define and describe the media and digital competencies for Polish pupils, students, and teachers were chosen.

In 2012, the Modern Poland Foundation prepared a catalog of media competencies, called Digital Future, this time commissioned by the Ministry of Culture and National Heritage under the auspices of the Ministry of Administration and Digitalization and the Ministry of National Education (currently the Ministry of Education and Science) [66].

In 2014, the same foundation and the National Audiovisual Institute (currently National Film Institute-FINA) prepared the catalog of media, digital, and information competencies as a guideline for the educational process realized in schools [67]. The range of the competencies was extended from pupils in primary schools (age 7) up to university students.

In 2019, a Model of Media, Information, and Digital Education was developed. The report was published by the Center of Citizenship Education, FINA, Modern Poland Foundation, Digital Dialogue Association, and the Polish Association of Media Education [68].

All of those reports focus on digital and media competencies that should be taught at public schools at all levels of education in Poland. They strongly emphasize the necessity of acquiring those particular competencies to search for, gather, and select information, as well as be a safe (in terms of cybersecurity) Internet user. The authors of those reports also emphasize digital exclusion prevention and providing equal opportunities to all students and pupils in Poland.

In 2018 [69] and 2019 [70], two major types of research were conducted to confront those theoretical assumptions with the actual situation of Polish pupils and students. The main objective of those studies was to establish how Polish pupils and students use media and the Internet. On a more detailed level, research questions for those studies focused on the habits and routines of media usage by Polish pupils and students, their awareness of threats related to the digital environment, their fluency in media usage, and the purposes of their media and digital environment usage.

In 2020, the situation in education changed globally due to the COVID-19 pandemic. The teaching process was shifted to remote learning [71]. Both students and teachers faced the necessity to use Internet tools in education broadly [72]. Additionally, the situation required both groups' fluency in digital and media competencies to use the Internet tools to conduct and participate in classes, retrieve information, and self-develop.

After half a year of school lockdown, in September 2020, the Institute for Labor Market Analyses in Warsaw, Poland, prepared a report called "Digital competencies and remote learning in the European Union" [73]. The report showed the outlines for digital education in chosen EU countries, as well as the possible scenarios, including both opportunities and threats, for digital education after the COVID-19 pandemic [74].

All of the reports mentioned above are a baseline to determine the range and components of the terms media literacy and digital literacy, which answers RQ1. The understanding of those terms is the background for clarification of what sort of skills are required for Polish pupils and students, what the fields are for educating them to ensure their digital competencies, and, last but not least, whether the skills offered to be developed by the Polish educational system are sufficient for the changing environment. The comparison of media and digital competencies defined in Polish reports with the European ones answers RQ2. Finally, the analysis of the reports on media and digital competencies, prepared after the outbreak of the COVID-19 pandemic, answers RQ3. 


\section{Results}

The first and the most important correlation mentioned in all of the reports focuses on the education level and fields in which Polish students and pupils should develop their media competencies. The most-cited authors in the Polish education papers report from 2014 divide digital skills and media competencies, considering the purpose of media usage and the necessary means of proper media usage [67]. The emphasized sections are presented in Table 1.

Table 1. Digital skills and media competencies: media usage perspective.

\begin{tabular}{cc}
\hline Skill and Competencies & Purpose of Media Usage \\
\hline $\begin{array}{c}\text { Ability to search, retrieve, select, use, and verify information } \\
\text { The necessary skills to communicate effectively in a media environment } \\
\text { Language competencies necessary to understand media content } \\
\text { Production of media content }\end{array}$ & $\begin{array}{c}\text { Information usage } \\
\text { The unit in the media environment } \\
\text { Media language } \\
\text { Creative media usage }\end{array}$ \\
Safe usage of Internet devices & $\begin{array}{c}\text { Ethics and values in media communication } \\
\text { Cybersecurity }\end{array}$ \\
$\begin{array}{c}\text { Responsibilities and laws of the Internet users, as well as the role of organizations } \\
\text { appointed to defend those laws }\end{array}$ & Law in media communication \\
$\begin{array}{c}\text { The value of information, as well as the principles of media organization function } \\
\text { The basics of computer usage, as well as the design and IT thinking process }\end{array}$ & Media economics \\
The safe usage of mobile devices & Mobile security
\end{tabular}

Those described and classified fields of digital and media competencies are universal for all media and Internet users. Nevertheless, the main objective of such a classification was to correlate them with education level. To do so, the stages of school education in Poland were divided based on students' age and correlated with the specific skills and competencies from the fields below acquired in every level of school education. These stages are presented in Table 2.

Table 2. Polish school education stages: age perspective.

\begin{tabular}{cc}
\hline Students' Age & Educational Stages \\
\hline $4-6$ years old & Kindergarten \\
$7-9$ years old & The beginning of primary education \\
$10-12$ years old & The middle of primary education \\
$13-15$ years old & The end of primary education \\
$16-18$ years old & Secondary school \\
19 years old and above & Higher education \\
$4-6$ years old & Kindergarten \\
\hline
\end{tabular}

In this report, a set of competencies called "the standard" was also defined, which should be presented by every adult.

Worth emphasizing is that the catalog of media competencies was prepared mainly by the non-governmental organization called Nowoczesna Polska (Modern Poland). In 2012, the same organization published the catalog called "Digital future", which was a preliminary stage for the 2014 report version. The structures of both reports are very similar, especially in terms of merit and content. The same fields of competencies had been drawn. However, the main difference between the reports from 2012 and 2014 is that the levels of digital competencies presented by the students was diverse in the second report. The students on every level of education may present their skills from a particular field in three different stages: minimum, optimum, and master. This diversification allows verifying the skill (whether the student has obtained it or not) and determining the level of competence.

Both of the reports mentioned above focus on the range of digital and media competencies that should be thought of in the Polish education system. In 2019, another non-governmental organization, the Center of Citizenship Education, published the report 


\begin{abstract}
"Model of Media, Information, and Digital Education" [68]. In this paper, the authors stated that the main objective of this model is to prepare an efficient tool for all the Polish teachers and principals of public schools to build teaching programs adequate for the rapidly changing digital environment. In contrast to previously analyzed reports, here, the authors divided the competencies into two types: professional and personal media, and informative and digital competencies (MIDCs). The authors defined professional MIDCs as several teachers' abilities, and we present them in Table 3.
\end{abstract}

Table 3. Teachers' professional media, informative and digital competencies.

\begin{tabular}{|c|c|}
\hline Teachers' Abilities & Connection with the Professional MIDCs \\
\hline $\begin{array}{c}\text { Using digital means of communication to communicate efficiently at school } \\
\text { with students and other teachers; using ICT to collaborate with other teachers; } \\
\text { using digital sources and media to learn how to use ICT; participating in } \\
\text { workshops and courses, which allow developing digital and } \\
\text { media competencies }\end{array}$ & Professional development \\
\hline $\begin{array}{l}\text { Searching and selecting valuable digital resources; creating open-source digital } \\
\text { resources; sharing previously created resources in the teaching process }\end{array}$ & $\begin{array}{l}\text { Usage of media, informative, and } \\
\text { digital resources }\end{array}$ \\
\hline $\begin{array}{l}\text { Using media in the teaching process; using ICT to develop interactions with } \\
\text { students; enabling students to use ICT for educational purposes }\end{array}$ & Teaching and learning \\
\hline $\begin{array}{c}\text { Using ICT in evaluating students' performance as well as in feedback; using } \\
\text { digital resources for planning lessons }\end{array}$ & Evaluation and grading \\
\hline $\begin{array}{c}\text { Ensuring access to digital resources for all students; using ICT for the creative } \\
\text { engagement of students }\end{array}$ & Strengthening the learners \\
\hline $\begin{array}{l}\text { Talking with students about their usage of media, e.g., social media or } \\
\text { YouTube; teaching information retrieval in a digital environment; encouraging } \\
\text { students to discuss proper and safe media usage }\end{array}$ & $\begin{array}{l}\text { Development of learners' media, informative, } \\
\text { and digital competencies }\end{array}$ \\
\hline
\end{tabular}

In turn, the authors defined the personal MIDCs of students as their abilities, as given in Table 4.

Table 4. Students' personal media, informative, and digital competencies.

\begin{tabular}{|c|c|}
\hline Students' Abilities & Connection with the Personal MIDCs \\
\hline $\begin{array}{c}\text { Using digital means of communication (including social media) and digital } \\
\text { devices, e.g., smartphone, webcam, or video games console; creating news, } \\
\text { posts, and online documents; solving technical problems with digital devices; } \\
\text { creative usage of the Internet }\end{array}$ & Media and digital devices usage \\
\hline $\begin{array}{c}\text { Using a varied range of information sources, verifying and comparing } \\
\text { gathered information; estimating credibility of information; being aware of } \\
\text { media misinformation and fake news; fact checking }\end{array}$ & Information usage \\
\hline $\begin{array}{l}\text { Being aware of different types of media genres; discussing media messages; } \\
\text { being aware that the media cover only a part of presented reality; } \\
\text { understanding different business canvases for media enterprises }\end{array}$ & Critical reception of media messages \\
\hline $\begin{array}{l}\text { Being aware of threats related to the digital environment; recognition of threats } \\
\text { related to misinformation; avoiding logging into personal accounts in public } \\
\text { places; using security applications; not using hate speech online }\end{array}$ & Safe media usage \\
\hline $\begin{array}{l}\text { Engaging socially through media; entering public discussion; taking part in } \\
\text { social events through media }\end{array}$ & Active media usage \\
\hline
\end{tabular}

It is worth emphasizing that the recommendations for implementing the model into teaching and learning practice refer to a wide range of institutions related to education, such as schools, ministries, and non-governmental organizations, but also to parents or public libraries.

The authors of the Media, Information, and Digital Education Model were aware of the two previously mentioned studies: "EU Kids online 2018" [69] and "Teenagers 3.0" [70]. In the first one, researchers focused on [69]:

- $\quad$ The usage of the Internet by pupils at home and school; 
- The feeling of being safe online;

- Cyberbullying in a peer group;

- Sexting among teenagers;

- Hate speech among teenagers.

The Polish authors of this study questioned 1433 pupils between 9 and 17 years old. Simultaneously, a similar study was conducted in 15 other countries of the European Union.

The second study, "Teenagers 3.0", was conducted only in Polish schools on a group of 1173 students (from primary and secondary schools, age 14 to 16 years old). Some of the issues that the authors focused on were similar to those from the diagnosis mentioned above. The authors investigated [70]:

- Usage (frequency and purpose) of the Internet;

- Usage of social media platforms;

- Self-benefits from using the Internet;

- Usage of ICT at school and in the self-education process;

- Privacy online and cybersecurity;

- Legal awareness of the Internet and ICT usage.

In September 2020, shortly after the COVID-19 pandemic outbreak, the Institute for Labour Market Analyses in Warsaw published a set of recommendations and scenarios for schools, related to European Commission guidelines, delivered to the public as operational programs and agendas. The crucial document for strategic students' competencies development, mentioned in the report, is the Digital Education Action Plan. Based on public consultation in 2020, it has been stated that the COVID-19 pandemic, which caused, among other effects, schools to shut down and the shift to distance learning, enforced two strategic priorities for the Polish government. The first one was to support the development of a highly effective digital education; the second one was to develop digital competencies and skills among students and teachers in Polish schools. As the European Commission states, according to the results of public consultation, 95\% consider that the COVID-19 pandemic marks a turning point for how technology is being used in education and training [75].

Based on all presented reports and studies, one can conclude that media and digital literacy among Polish pupils and students have been broadly discussed in past years. The catalogs of media and digital competencies, prepared by non-governmental organizations, show certain fields in which schools, as well as other education-related institutions, should develop students' skills to make them aware of the digital environment they are in. On the other hand, the conducted studies do not correlate with the frames published in presented catalogs of competencies. The structure of questionnaires used in studies is self-diagnosis oriented, which means that students answering the questions in certain fields do not present required skills but merely their opinion of having them.

\section{Discussion}

When talking about digital literacy in general, it is reasonable to mention that it is a phenomenon rather difficult to define- today, there exist over a hundred models and frameworks attempting to capture various dimensions of digital literacies. Moreover, researchers noticed that the interpretation of digital literacy could vary depending on the discipline where it is applied-for instance, teachers and students of humanities may consider it differently to those working in computer sciences [14]. Researchers such as Tejedor et al. (2020) [20] support this opinion, stating that the concept of digital literacy has not yet been standardized since it has been researched from many different perspectives, such as media studies, educational studies, computer science, information science, and librarianship.

Researchers note that even though young people seem to be growing up immersed in technology, using more specific technology for learning requires different skills and strategies than just chatting online or watching movies [18]. However, Radovanovic et al. (2015) [58] revealed that teachers of older generations do not teach young students the necessary digital literacy skills since many of them do not possess such skills themselves. Most academic teachers agree that digital literacy should be conceptualized as a series 
of characteristics rather than a discrete and static checklist of skills. These characteristics are supposed to change over time as new skills and literacies emerge due to changes and technological evolution [18]. Lankshear and Knobel (2015) state text-mediated interactions such as communicating and relating cannot be reduced to simply transmitting and receiving information [19]. When we define digital literacy purely or predominantly in terms of interacting with information, we distort social practice and human intentions.

The statements given above, as well as the research results presented in the paper, allow stating that the digital literacy of pupils, students, and teachers of all ages is a question of high priority. Digital competencies are often treated carelessly-a person who knows how to use Facebook or type a simple text is believed to be digitally competent and possess all the required technical skills. It seems that more research should be conducted to make sure digital literacy becomes an issue of state-level importance.

At the beginning of 2020, when teachers and learners all over the world had shifted online and had achieved that only in a few weeks due to the coronavirus pandemic, we had a unique chance to observe how theories of globalization of technology and education, that we have been developing for decades, are experiencing the immense reality check our world has faced so far [76]. According to UNESCO data, it is not surprising that as of 14 April 2020, the activity of 1.6 billion (91.3\%) pupils and students in 188 countries was limited because of COVID-19 [73].

The authors of the report "Digital competencies and remote learning in the European Union" [73] provide information about some good practices implemented to face the pandemic. For instance, in Finland, the National Agency for Education for a long time has already been advising schools on how to plan and organize various types of flexible learning, with the application of virtual platforms. In Spain, the Ministry of Education, through the National Institute of Educational Technology and Teacher Education, and in cooperation with the Spanish Radio and Television Corporation, broadcasts educational material for students on television and online platforms. In the Czech Republic, public television broadcasts educational programs for students under the professional supervision of the Ministry of Education, Youth and Sports.

At the same time, Selwyn and Jandrić (2020) share their observations about schools in Australia [76]. They state that not a city in this country has had a homogenous remote studying experience. Moreover, unfortunately, no school would have a unitary form of learning online.

Additionally, the report mentioned above distinguishes the major challenges the educational sector has faced due to the pandemic: balance between online lessons and offline student activities; ensuring the emotional wellbeing of students; providing access to digital devices; proper management of IT infrastructure; and a creative approach to adapting mobile devices and digital platforms for teaching. Finally, it is suggested that the following solutions should be implemented to educational policy not as emergency measures, but as standard and common practices: conducting exams online; using digital educational solutions in terms of shorter learning time; familiarizing teachers with digital technologies; and using solutions applied in other educational systems (with the recommendation of careful documentation of such solutions by countries that implement them).

Implementation of solutions connected with learning online is necessary today, in the era of constant movement and mobility, when it becomes difficult to make young people stay in one place [18]. As proof of this statement, we can consider the research of McGuinness and Fulton (2019). They found that students consider the flexibility provided by e-learning as its strength, because students learn at their own pace and can complete tasks anywhere and anytime [30]. However, Burton et al. (2015) revealed that for students, the need to be part of a peer group, as well as the need to belong to their educational institution, is critical [18]. Online learning, for sure, offers greater flexibility than faceto-face study; however, educator support will always be vital to ensuring quality and facilitating positive learning experiences for students. The lack of personal interaction and often limited exchanges can require extra time and, first of all, energy to establish an online 
learning community as strong as the one possible only in face-to-face education. In addition, students quickly realize how much they rely on teacher explanations of the content.

In addition to the observations mentioned above, the study conducted among Polish first-year students showed that students in this country mostly worry about their digital skills required for learning online, and these students generally expect to enjoy learning online. Yet, it is mainly because they realize the necessity of such a format of education, and they are aware that they will have no choice for some time. Nevertheless, the students claim they would willingly return to their face-to-face classroom activities when it is possible [71]. The other study, conducted earlier, showed that right after the global shift towards online education (spring 2020), the students were much less happy about studying online, since the educational systems of universities (not all of them, however) were not well prepared for the challenges that appeared [72].

Speaking about learning online (as well as "offline"), it is impossible not to mention teachers, who also faced certain problems because of the shift toward learning online. It was found that academic teachers had mixed perceptions of e-learning opportunities. Some of them faced several challenges: lack of training to use e-learning technologies, additional time needed for teaching, computer competencies needed, and perceptions of students abilities to take advantage of e-learning. It was suggested that it is essential for educational institutions to build the trust of their teachers by supporting their digital education, because only this way can institutions guarantee the high quality of online education and its favor among teachers and students [30].

To sum up, it can be stated that the digital competencies of students and teachers in the countries affected by coronavirus were at very different levels, and for many countries this level was relatively low. Many schools and universities were not prepared for the $100 \%$ shift toward online learning, and it took some time for them to find proper solutions to guarantee a high level of work both for students/pupils and for teachers. This happened because, as it turns out, not all countries (Poland, for instance) pay much attention to the digital competencies of the youth and workers of the education system; some plans for digital education appear to exist only nominally, on paper. Therefore, it is essential for teachers to be aware of media and digital competencies and to develop them through teaching among students. In this paper, the classification of the competencies described is presented, as well as the students' and teachers' skills that may be developed, which can be considered a contribution to change in the Polish education system.

\section{Conclusions}

This paper analyzed the state-of-the-art digital and media literacies in the Polish education system with pre- and post-COVID-19 perspectives. Three research questions were posed in the paper. As the answer to the first one, the skills included in the term "digital and media competencies" for Polish young people and students were identified. Such skills cover information usage, media environment and language, creative media usage, ethics, cybersecurity, the law in media communication, media economics, digital competencies, and mobile security. On the other hand, it was identified that the current education system in Poland does not provide students with this set of skills within the years of schooling. Answering the second research question, the authors noticed that during the COVID-19 pandemic, many European countries and the European Commission quickly released sets of recommendations for young people to participate in online education. Providing students with a set of digital and media competencies in a period when they are almost forced to study online is very helpful. As the answer to the third research question, the authors identified that young people and students feel very comfortable with new technologies and the requirements defined by the set of digital and media literacies; however, they are not entirely satisfied with the option of distance learning. The authors contribute to the subject by proving that the importance of digital and media competencies of pupils and students is underestimated; some countries show a very low level of development for these competencies. This might not have been significant before 
the COVID-19 pandemic. However, when it broke out, it became clear that many schools and higher education institutions were not prepared enough - not only with regard to students but also from the side of their teachers. It is necessary to stress that such a problem was not observed in all countries affected by COVID-19. For instance, Poland appeared to require certain changes and improvements to be made in the policy connected with digital and media education at schools and higher education institutions.

Author Contributions: Conceptualization, K.C. and A.S.; methodology, K.C.; formal analysis, K.C. and P.R.; investigation, K.C. and P.R.; resources, K.C. and P.R.; data curation, K.C. and P.R.; writingoriginal draft preparation, K.C. and P.R.; writing-review and editing, K.C., P.R. and M.R.; supervision, A.S.; project administration, A.S. and K.C.; funding acquisition, A.S. All authors have read and agreed to the published version of the manuscript.

Funding: This research received no external funding.

Institutional Review Board Statement: Not applicable.

Informed Consent Statement: Not applicable.

Conflicts of Interest: The authors declare no conflict of interest.

\section{References}

1. Cooley, R.E.; Roach, D.A. A Conceptual Framework. In Competence in Communication: A Multidisciplinary Approach; Bostrom, R., Ed.; Sage: Beverly Hills, CA, USA, 1984.

2. Jakobson, R. Linguistics and Poetics. In Style in Language; Sebeok, T., Ed.; Massachusetts Institute of Technology Press: Cambridge, UK, 1960; pp. 350-377.

3. Hymes, D.H. On Communicative Competence. In Sociolinguistics; Pride, J.B., Holmes, J., Eds.; Penguin Education, Penguin Books Ltd.: Baltimore, MD, USA, 1972; pp. 269-293.

4. Racine, N. Visual Communication: Understanding Maps, Charts, Diagrams, and Schematics; Learning Express: New York, NY, USA, 2002.

5. Mirzoeff, N. An Introduction to Visual Culture; Routledge: London, UK, 1999.

6. Sims, E.; O'Leary, R.; Cook, J.; Butland, G. Visual literacy: What is it and do we need it to use learning technologies effectively. In Proceedings of the 19th Annual Conference of the Australian Society for Computers in Tertiary Education (ASCILITE), Auckland, New Zealand, 8-11 December 2002.

7. Brill, J.M.; Maribe Branch, R. Visual Literacy Defined-The Results of a Delphi Study: Can IVLA (Operationally) Define Visual Literacy? J. Vis. Lit. 2007, 27, 47-60. [CrossRef]

8. Felten, P. Visual Literacy. Chang. Mag. High. Learn. 2008, 40, 60-64. [CrossRef]

9. Lester, P.M. Visual Communication: Images with Messages; Cengage Learning: Boston, MA, USA, 2013.

10. Naughton, J. The evolution of the Internet: From military experiment to General Purpose Technology. J. Cyber Policy 2016, 1, 5-28. [CrossRef]

11. Fernández-Montalvo, J.; Peñalva, A.; Irazabal, I.; López-Goñi, J.J. Effectiveness of a digital literacy programme for primary education students. Cult. Educ. 2017, 29,1-30. [CrossRef]

12. Galán, J.G. Media education as theoretical and practical paradigm for digital literacy an interdisciplinary analysis. Eur. J. Sci. Theol. 2015, 11, 31-44.

13. Miranda, P.; Isaias, P.; Pifano, S. Digital Literacy in Higher Education: A Survey on Students' Self-Assessment. In Proceedings of the Lecture Notes in Computer Science (Including Subseries Lecture Notes in Artificial Intelligence and Lecture Notes in Bioinformatics) Held at 5th International Conference on Learning and Collaboration Technologies LCT 2018; 15-20 July 2018, Las Vegas, NV, USA; Springer: Berlin/Heidlberg, Germany, 2018; Volume 10925 LNCS, pp. 71-87.

14. Adachi, C.; Blake, D.; Riisla, K. Exploring digital literacy as a graduate learning outcome in higher education-An analysis of online survey. In Proceedings of the ASCILITE 2018-Conference Proceedings-35th International Conference of Innovation, Practice and Research in the Use of Educational Technologies in Tertiary Education: Open Oceans: Learning without Borders; Australasian Society for Computers in Learning in Tertiary Education (ASCILITE), Geelong, VI, Australia, 25-28 November 2018; pp. 292-297.

15. Maureen, I.Y.; van der Meij, H.; de Jong, T. Supporting Literacy and Digital Literacy Development in Early Childhood Education Using Storytelling Activities. Int. J. Early Child. 2018, 50, 371-389. [CrossRef]

16. Lafton, T. Digital literacy practices and pedagogical moments: Human and non-human intertwining in early childhood education. Contemp. Issues Early Child. 2015, 16, 142-152. [CrossRef]

17. Handley, F.J.L. Developing digital skills and literacies in UK higher education: Recent developments and a case study of the digital literacies framework at the university of Brighton, UK. Publ. Fac. Educ. Humanid. Campus Melilla 2018, 48, 109-126. [CrossRef] 
18. Burton, L.J.; Summers, J.; Lawrence, J.; Noble, K.; Gibbings, P. Digital literacy in higher education: The rhetoric and the reality. In Myths in Education, Learning and Teaching: Policies, Practices and Principles; Palgrave Macmillan: London, UK, 2015; pp. 151-172; ISBN 9781137476982.

19. Lankshear, C.; Knobel, M. Digital Literacy and Digital Literacies: Policy, Pedagogy and Research Considerations for Education. Nord. J. Digit. Lit. 2015, 2015, 8-20. [CrossRef]

20. Tejedor, S.; Cervi, L.; Pérez-Escoda, A.; Jumbo, F.T. Digital literacy and higher education during COVID-19 lockdown: Spain, Italy, and Ecuador. Publications 2020, 8, 1-17. [CrossRef]

21. Lund, A.; Furberg, A.; Gudmundsdottir, G.B. Expanding and embedding digital literacies: Transformative agency in education. Media Commun. 2019, 7, 47-58. [CrossRef]

22. Lanham, R. Digital literacy. Sci. Am. 1995, 273, 160-161.

23. Erstad, O. Content in motion: Remixing and learning with digital media. In Digital Content Creation. Perceptions, Practices $\mathcal{E}$ Perspectives; Drotner, K., Schrøder, K.C., Eds.; Peter Lang Publishing Group: London, UK, 2010.

24. Spante, M.; Hashemi, S.S.; Lundin, M.; Algers, A. Digital competence and digital literacy in higher education research: Systematic review of concept use. Cogent Educ. 2018, 5, 1-21. [CrossRef]

25. Pool, C.R. A New Digital Literacy: A Conversation with Paul Gilster. Educ. Leadersh. 1997, 55, 6-11.

26. Martin, A. A european framework for digital literacy. Nord. J. Digit. Lit. 2006, 1, 151-161. [CrossRef]

27. Bawden, D. Information and digital literacies; a review of concepts. J. Doc. 2001, 57, 218-259. [CrossRef]

28. Chan, B.S.K.; Churchill, D.; Chiu, T.K.F. Digital Literacy Learning in Higher Education Through Digital Storytelling Approach. J. Int. Educ. Res. 2017, 13, 1-16. [CrossRef]

29. European Commission Council Recommendation on Key Competences for Lifelong Learning | Education and Training. Available online: https:/ / ec.europa.eu/education/education-in-the-eu/council-recommendation-on-key-competences-for-lifelonglearning_en (accessed on 5 July 2021).

30. McGuinness, C.; Fulton, C. Digital literacy in higher education: A case study of student engagement with e-tutorials using blended learning. J. Inf. Technol. Educ. Innov. Pract. 2019, 18, 1-28. [CrossRef]

31. Song, Y. Multimedia news storytelling as digital literacies: An alternative paradigm for online journalism education. Journalism 2018, 19, 837-859. [CrossRef]

32. Scharrer, E.; Ramasubramanian, S. Intervening in the Media's Influence on Stereotypes of Race and Ethnicity: The Role of Media Literacy Education. J. Soc. Issues 2015, 71, 171-185. [CrossRef]

33. López, L.; Aguaded, M.C. Teaching media literacy in colleges of education and communication. Comunicar 2015, 22, 187-195. [CrossRef]

34. Aguaded-Gómez, J.I. Media proficiency, an educational initiative that cannot wait. Comunicar 2012, 20, 7-8. [CrossRef]

35. Kesler, T.; Tinio, P.P.L.; Nolan, B.T. What's Our Position? A Critical Media Literacy Study of Popular Culture Websites With Eighth-Grade Special Education Students. Read. Writ. Q. 2016, 32, 1-26. [CrossRef]

36. Nagle, J. Twitter, cyber-violence, and the need for a critical social media literacy in teacher education: A review of the literature. Teach. Teach. Educ. 2018, 76, 86-94. [CrossRef]

37. De Abreu, B.S.; Mihailidis, P.; Lee, A.Y.L.; Melki, J.; McDougall, J. International Handbook of Media Literacy Education; Taylor and Francis Inc.: Abingdon, UK, 2017; ISBN 9781315628110.

38. Scull, T.M.; Kupersmidt, J.B.; Weatherholt, T.N. The effectiveness of online, family-based media literacy education for substance abuse prevention in elementary school children: Study of the Media Detective Family Program. J. Community Psychol. 2017, 45, 796-809. [CrossRef]

39. Lee, A.Y.L. Media education in the School 2.0 era: Teaching media literacy through laptop computers and iPads. Glob. Media China 2016, 1, 435-449. [CrossRef]

40. National Association for Media Literacy Education Media Literacy Defined. Available online: https://namle.net/resources/ media-literacy-defined/ (accessed on 5 July 2021).

41. Reyna, J.; Hanham, J.; Meier, P.C. A framework for digital media literacies for teaching and learning in higher education. E-Learning Digit. Media 2018, 15, 176-190. [CrossRef]

42. Hashimoto, A.; Clayton, M. Visual Design Fundamentals: A Digital Approach; Charles River Media, Independence; CENGAGE Learning: Boston, MA, USA, 2009.

43. Malamed, C. Visual Design Solutions; John Wiley \& Sons, Inc.: Hoboken, NJ, USA, 2015; ISBN 9781119153801.

44. Stockman, S. How to Shoot Video That Doesn't Suck: Advice to Make Any Amateur Look Like a Pro; Workman Publishing Company: New York, NY, USA, 2011.

45. Spinks, N.; Wells, B.; Meche, M. Netiquette: A behavioral guide to electronic business communication. Corp. Commun. An Int. J. 1999, 4, 145-155. [CrossRef]

46. Strawbridge, M. Netiquette: Internet Etiquette in the Age of the Blog; Software Reference Ltd.: London, UK, 2006.

47. Hinrichsen, J.; Coombs, A. The five resources of critical digital literacy: A framework for curriculum integration. Res. Learn. Technol. 2013, 21. [CrossRef]

48. Poore, M. Digital Literacy: Human Flourishing and Collective Intelligence in a Knowledge Society. Polit. Sci. 2011, 19, 20-26. 
49. Burton, L.J.; Lawrence, J.; Summers, J.; Gibbings, P.; Noble, K. Developing DART: A Digital Learning Tool to Facilitate Equity and Access in the Contemporary Higher Education Context. In Proceedings of the Open and Distance Learning Association of Australia Distance EducationSummit (ODLAA 2013): Education Across Space and Time: Meeting the Diverse Needs ofthe Distance Learner, Sydney, Australia, 4-6 February 2013.

50. Ala-Mutka, K. Mapping Digital Competence: Towards a Conceptual Understanding. Jt. Res. Cent. Tech. Note. Publ. Off. Eur. Union 2011, 7-60. [CrossRef]

51. Buckingham, D. Defining digital literacy-What do young people need to know about digital media? Nord. J. Digit. Lit. 2006, 1, 263-277. [CrossRef]

52. Prensky, M. Digital Natives, Digital Immigrants. In On the Horizon; MCB University Press: Bingley, UK, 2001 ; Volume 9.

53. Romero, M.; Guitert, M.; Sangrà, A.; Bullen, M. Do UOC Students Fit in the Net Generation Profile? An Approach to their Habits in ICT Use 1 i s (SNA). Int. Rev. Res. Open Distance Learn. 2013, 14, 158-181. [CrossRef]

54. Kennedy, D.M.; Fox, B. “Digital natives”: An Asian perspective for using learning technologies. Int. J. Educ. Dev. Using ICT 2013, 9, 65-79.

55. Gilster, P. Digital Literacy; Wiley Computer Pub: New York, NY, USA, 1997.

56. Stracke, C.M. Quality frameworks and learning design for open education. Int. Rev. Res. Open Distance Learn. 2019, $20,180-203$. [CrossRef]

57. Stracke, C.M.; Kameas, A.; Vassiliadis, B.; Sgouropoulou, C. The Quality of Open Online Education: Towards a Reference Framework for MOOCs. In Proceedings of the IEEE Global Engineering Education Conference, Athens, Greece, 25-28 April 2017; pp. 1712-1715.

58. Radovanović, D.; Hogan, B.; Lalić, D. Overcoming digital divides in higher education: Digital literacy beyond Facebook. New Media Soc. 2015, 17, 1733-1749. [CrossRef]

59. Fedorov, A.; Levitskaya, A.; Camarero, E. Curricula for media literacy education according to international experts. Eur. J. Contemp. Educ. 2016, 17, 324-334. [CrossRef]

60. Langub, L.W.; Lokey-Vega, A. Rethinking Instructional Technology to Improve Pedagogy for Digital Literacy: A Design Case in a Graduate Early Childhood Education Course. TechTrends 2017, 61, 322-330. [CrossRef]

61. Brudermann, T.; Aschemann, R.; Füllsack, M.; Posch, A. Education for Sustainable Development 4.0: Lessons Learned from the University of Graz, Austria. Sustainability 2019, 11, 2347. [CrossRef]

62. Beynaghi, A.; Trencher, G.; Moztarzadeh, F.; Mozafari, M.; Maknoon, R.; Leal Filho, W. Future sustainability scenarios for universities: Moving beyond the United Nations Decade of Education for Sustainable Development. J. Clean. Prod. 2016, 112, 3464-3478. [CrossRef]

63. Ricard, M.; Zachariou, A.; Burgos, D. Digital Education, Information and Communication Technology, and Education for Sustainable Development. In Lecture Notes in Educational Technology; Springer: Cham, Switzerland, 2020; pp. $27-39$.

64. Daniel, B.K. Big Data and data science: A critical review of issues for educational research. Br. J. Educ. Technol. 2019, 50, 101-113. [CrossRef]

65. Cicha, K. Kompetencja wizualna, czyli jak zrozumieć media. In Język a Media, Wzory Języka We Współczesnych Mediach; Skowronek, B., Horyń, E., Walecka-Rynduch, A., Eds.; Wydawnictwo Naukowe Uniwersytetu Pedagogicznego w Krakowie: Krakow, Poland, 2018; pp. 132-147; ISBN 978-83-8084-120-8.

66. Dąbrowska, A.J.; Drzewiecki, P.; Górecka, D.; Gruhn, A.; Hojnacki, L.; Jasiewicz, J.; Lipszyc, J.; Majewski, W.; Murawska-Najmiec, E.; Stunża, G.; et al. Cyfrowa przyszłość. In Katalog Kompetencji Medialnych i Informacyjnych; Fundacja Nowoczesna Polska: Warszawa, Poland, 2012.

67. Budzisz, W.; Cywińska, M.; Czajka, R.; Dabrowska, A.; Drzewiecki, P.; Głowacka, D.; Gnoiński, W.; Gruhn, A.; Hojnacki, L.; Jasiewicz, J.; et al. Katalog Kompetencji Medialnych, Informacyjnych i Cyfrowych; Fundacja Nowoczesna Polska: Warszawa, Poland, 2014.

68. Górecka-O'Connor, D.; Komorowski, T.; Korzeniowska, E.; Krywoszejew, B.; Pacewicz, A.; Ptaszek, G. Model Edukacji Medialnej, Informacyjnej i Cyfrowej; Centrum Edukacji Obywatelskiej, Fundacja Nowoczesna Polska, Polskie Towarzystwo Edukacji Medialnej, Polski Komitet do spraw UNESCO, Fundacja Szkoła z Klasa, Filmoteka Narodowa-Instytut Audiowizualny, Stowarzyszenie Cyfrowy Dialog: Kraków, Warszawa, 2019.

69. Pyżalski, J.; Zdrodowska, A.; Tomczyk, Ł.; Abramczuk, K. Polskie Badanie EU Kids Online 2018. NajważNiejsze Wyniki i Wnioski; Wydawnictwo Naukowe UAM: Poznań, Poland, 2019.

70. Bochenek, M.; Lange, R. NASTOLATKI 3.0. Raport z Ogólnopolskiego Badania Uczniów; NASK: Warszawa, Poland, 2019.

71. Cicha, K.; Rizun, M.; Rutecka, P.; Strzelecki, A. COVID-19 and Higher Education: First-Year Students' Expectations toward Distance Learning. Sustainability 2021, 13, 1889. [CrossRef]

72. Rizun, M.; Strzelecki, A. Students' acceptance of the COVID-19 impact on shifting higher education to distance learning in Poland. Int. J. Environ. Res. Public Health 2020, 17, 6468. [CrossRef]

73. PARP. Kompetencje Cyfrowe i Nauczanie Zdalne w Unii Europejskiej; PARP: Warszawa, Poland, 2020.

74. Springer, S.; Zieger, M.; Strzelecki, A. The rise of infodemiology and infoveillance during COVID-19 crisis. One Health 2021, 13, 100288. [CrossRef] 
75. European Commission Digital Education Action Plan 2021-2027 Resetting Education and Training for the Digital Age; European Commission: Brussels, Belgium, 2020.

76. Selwyn, N.; Jandrić, P. Postdigital Living in the Age of Covid-19: Unsettling What We See as Possible. Postdigital Sci. Educ. 2020, 2, 989-1005. [CrossRef] 